DOI: https://doi.org/10.47405/mjssh.v6i8.969

\begin{tabular}{|c|c|}
\hline 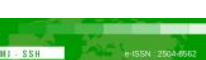 & Malaysian Journal of Social Sciences and Humanities (MJSSH) \\
\hline Malaysian Journal of & Volume 6, Issue 8, August 2021 \\
\hline (MJ-SSH) & e-ISSN : 2504-8562 \\
\hline & $\begin{array}{l}\text { Journal home page: } \\
\text { www.msocialsciences.com }\end{array}$ \\
\hline
\end{tabular}

\title{
Kedaulatan Raja-Raja Melayu Melangkaui Peruntukan Perlembagaan Persekutuan: Implikasinya ke atas Sistem Raja Berperlembagaan di Malaysia
}

\author{
Nur Ezan Rahmat ${ }^{1}$ Norazlina Abdul Aziz¹, Mazlina Mohamad Mangsor¹, Muhamad Ikhwan Mohd \\ Zain'1 \\ 1Fakulti Undang-Undang, Universiti Teknologi MARA, \\ 40450 Shah Alam, Selangor, Malaysia
}

Correspondence: Nur Ezan Rahmat (nurezan@uitm.edu.my)

\begin{abstract}
Abstrak
Malaysia mengamalkan sistem Raja Berperlembagaan iaitu Raja harus bertindak mengikut peruntukan perlembagaan yang telah ditetapkan sekaligus menutup ruang kepada kebebasan memerintah (kuasa mutlak) dalam sistem pentadbiran negara. Disebabkan ada beberapa keadaan dalam Perlembagaan Malaysia yang tidak menyebut secara jelas tentang kedaulatan dan kuasa Raja-Raja Melayu, maka RajaRaja Melayu adakalanya menggunakan budi bicara melangkaui peruntukan dalam perlembagaan. Tindakan ini serigkali dicabar keabsahahnya. Objektif penyelidikan ini adalah untuk mengkaji sejauh manakah kedaulatan dan kuasa Raja-Raja Melayu boleh melangkaui peruntukan di bawah Perlembagaan Persekutuan serta implikasinya terhadap masyarakat, kerajaan dan negara. Penyelidikan ini menggunakan kaedah kualitatif beserta kajian lapangan. Data yang berasaskan sumber primer, sekunder, pemerhatian dan temu bual telah dianalisa untuk mendapatkan hasil bagi kajian ini. Hasil dapatan penyelidikan ini dapat menerangkan kepada masyarakat dan kerajaan betapa pentingnya kedaulatan Raja-Raja Melayu di bawah Perlembagaan Persekutuan, sekaligus menekankan beberapa situasi yang Raja-Raja Melayu boleh menggunakan budi bicara untuk membuat sesuatu keputusan walaupun tidak termaktub di bawah Perlembagaan Persekutuan, demi kemaslahatan dan kesejahteraan masyarakat dan negara.
\end{abstract}

Kata kunci: Raja-Raja Melayu, Perlembagaan Persekutuan, Raja Berperlembagaan, Melangkaui Peruntukan

\section{The Sovereignty of the Malay Rulers Beyond the Provisions of the Federal Constitution: Implications on Monarchy System in Malaysia}

\begin{abstract}
Malaysia adopts a system of Constitutional Monarchy, which the King must act in accordance with the provisions of the constitution that have been set, thus closing the gap of absolute power in the country's administrative system. There are some situations that the Constitution does not mention explicitly the sovereignty and jurisdiction of the Malay Rulers, thus the Malay Rulers sometimes exercised their discretionary powers beyond the provision. The objective of this research is to study the extent of the authority and power of the Malay Rulers embracing beyond the provisions of the Federal Constitution. This research also looks at its implications on the society, government and the country. This research uses qualitative methodology with fieldwork. The data which is based on primary, secondary sources,
\end{abstract}


observations and interviews were analyzed to obtain results for this study. The findings managed to explain to the public and the government on how important the sovereignty is to the Malay Rulers under the Federal Constitution and there are situations where the Malay Rulers have the discretion to make a decision even if not enshrined in the Federal Constitution for the benefit and well-being of the community and the country.

Keywords: Malay Rulers, Federal Constitution, Constitutional Monarchy, Beyond the Provisions.

\section{Pengenalan}

Kedaulatan Raja-Raja Melayu merupakan satu elemen dan kedudukan yang sangat penting dalam sistem pemerintahan di Malaysia. Sejarah mencatatkan Malaysia telah mengamalkan sistem Raja Berperlembagaan sejak zaman pemerintahan kesultanan Melayu Melaka lagi. Seri Paduka Baginda Yang di-Pertuan Agong (selepas ini dirujuk sebagai YDPA) dipilih oleh Majlis Raja-Raja mengikut kaedah dan aturan yang telah ditetapkan dalam Jadual Ketiga Perlembagaan Persekutuan dan PeraturanPeraturan Majlis Raja-Raja. Walaupun kedudukan Raja-Raja diletakkan di peringkat teratas untuk kebanyakan struktur pentadbiran di Malaysia, namun mereka tetap tertakluk kepada Perlembagaan Persekutuan, sebagai undang-undang tertinggi yang menjadi asas kepada setiap undang-undang dan seluruh warganegara Malaysia. Sistem yang dikenali sebagai Raja Berperlembagaan, telah menjadi tunggak kepada ketenteraman, perlindungan hak asasi dan keselamatan Malaysia sekaligus menekankan peri pentingnya kepentingan institusi beraja di negara ini.

Secara umumnya, terdapat beberapa peristiwa utama telah berlaku di Malaysia yang telah menyentuh kuasa dan penglibatan daripada Yang Dipertuan Agong (YDPA) (Raja-Raja Melayu). Salah satu agenda besar negara ialah perubahan kuasa pemerintahan Malaysia yang melibatkan ketua kerajaan selepas pilihanraya ke-14. Perubahan yang melibatkan perlantikan Perdana Menteri ke-8 oleh YDPA menggunakan kuasa prerogatif yang diperuntukan di bawah Perkara 40(2)(a) dan dibaca bersama Perkara 43(2)(a) Perlembagaan Persekutuan memperlihatkan cara YDPA menangani desakan daripada ahli-ahli Dewan Rakyat. Perkara ini mengesahkan kebolehlaksanaan kuasa prerogatif perlembagaan yang diberikan kepada Ketua Eksekutif, iaitu YDPA, telah diuji dan dilaksanakan dengan teliti. Ini telah membantu dalam memelihara hak-hak rakyat untuk menikmati hak asasi mereka seperti yang dijamin di dalam Perlembagaan Persekutuan. Selain itu, peranan YPDA telah ditonjolkan ketika mententeramkan pertembungan di antara dua krisis besar negara iaitu krisis pergolakan politik dan krisis kesihatan pandemik COVID-19. Ini telah memperlihatkan bagaimana YDPA dan Raja-Raja mula menjadi tempat untuk memohon pembelaan oleh rakyat jelata, berlandaskan kepada Perlembagaan Persekutuan.

Tidak kurang juga, situasi tular yang memerlukan pengumuman darurat melibatkan kes pencemaran di Sungai Kim Kim, Johor, pada tahun 2019, telah mempengaruhi lebih daripada 20,000 orang dan penutupan 475 buah institusi pendidikan di negeri Johor. Dalam insiden ini, Parlimen Malaysia telah meluluskan usul untuk mengumumkan darurat, namun tidak dipersetujui oleh Eksekutif yang berada di bawah kuasa pentadbiran YDPA.

Kesemua perkara yang berlaku memerlukan penglibatan terus daripada YDPA dan Raja-Raja Melayu, kerana ianya tertakluk di bawah Perkara yang telah dinyatakan dalam Perlembagaan Persekutuan. Dalam Perlembagaan Persekutuan, terdapat beberapa Perkara yang menjelaskan secara langsung tentang kedaulatan Raja-Raja Melayu. Namun, ada juga yang dinyatakan secara tidak langsung, menyebabkan kedaulatan baginda melangkaui beberapa aspek perundangan dalam perlembagaan persekutuan tersebut. Ada pandangan mengatakan kuasa dan pengaruh sebenar Raja-Raja Melayu itu terletak pada diri dan institusi dan bukannya pada peruntukan perlembagaan dan undang-undang. Dengan kata lain, Raja-Raja masih memiliki kuasa tersimpan atau tersembunyi. Justeru, kajian ini telah dijalankan atas tujuan untuk melihat dan mengukur sejauh mana kuasa dan kedaulatan raja-raja melayu boleh mengatasi kuasa perlembagaan persekutuan yang merupakan asas perundangan di Malaysia. Dalam pada itu, kajian ini 
juga melihat adakah pelangkauan kuasa itu memberi impak kepada sistem raja berperlembagaan di Malaysia.

\section{Sorotan Literatur}

Hasil sorotan literatur berkaitan sistem beraja dapat disimpulkan bahawa banyak kajian berkaitan topik ini telah dilakukan. (MAIS, 2020; Nazri Muslim, 2020) semasa menulis mengenai pemerintah Malaysia, menekankan keperluan untuk memelihara institusi ini dan mengaitkannya dengan pemeliharaan hak bumiputera dan kesucian agama Islam. Dalam sebuah artikel yang ditulis oleh MAIS (2020), telah dinyatakan bahawa sumbangan besar penguasa Malaysia dapat dirumuskan dengan menganalisis sejarah berkaitan pemerintahan Melaka pada abad ke-13 yang berada di bawah Raja beragama Islam yang hebat dan telah meletakkan Melaka sebagai sebuah kerajaan dengan struktur pentadbiran yang komprehensif dan sistematik (Muhammad Shamsul, 2019; MAIS, 2020, Mohd Roslan dan et al., 2013). Sebab lain untuk memelihara sistem beraja yang dibincangkan oleh artikel ini adalah cara institusi ini berfungsi dalam mengekalkan perpaduan di negara berbilang kaum ini (MAIS, 2020; Nazri, 2020, Mohd Roslan dan et al, 2013). Menurut penulisan ini lagi, keputusan yang dibuat oleh penguasa adalah tidak berat sebelah tidak seperti gabungan parti mahupun ahli politik yang selalu merumuskan keputusan mereka berdasarkan sentimen. Kajian di dalam bidang ini juga seringkali mengaitkan institusi beraja dengan kedaulatan. Kedaulatan ialah konsep politik dan perundangan yang berkaitan dengan kekuasaan tertinggi dalam sesebuah negeri (Curzon, 2007). Kedaulatan adalah aspek utama yang mencorakkan prinsip perlembagaan dan memberikan legitimasi kepada sesebuah negeri atau kerajaan (Immanuel W., 2004). Kedaulatan juga ditakrifkan sebagai sebuah kerajaan yang melaksanakan 'de facto' kawalan pentadbiran terhadap sesebuah negara dan tidak tunduk kepada kerajaan lain (Greenberg, D. 2012). Dalam membincangkan senario di Malaysia, konsep kedaulatan haruslah dilihat daripada kerangka peribumi Malaysia itu sendiri. Kerangka peribumi bermaksud konsep kedaulatan itu perlu ditafsirkan mengikut kerangka undang-undang yang diwarisi dan dijunjung oleh peribumi selagi tidak bercanggah dengan Perlembagaan Persekutuan (Wan Ahmad Fauzi, 2018).

Tidak dapat dinafikan, sejarah Melayu telah merakamkan betapa besarnya peranan dan sumbangan RajaRaja Melayu. Bermula dari perkembangan Islam di Tanah Melayu sebagai pusat perdagangan dan penyebarannya sehingga kini, Raja-Raja Melayu telah diterima baik sebagai simbol perpaduan, kesinambungan agama, budaya, adab resam dan cara hidup. Hal ini sangat berkait rapat dengan sistem kerajaan dan dasar negara yang boleh bertukar setiap lima tahun, namun, pegangan moral, adab, kesopanan dan kesusilaan masyarakat Malaysia masih boleh dikekalkan dan dilindungi oleh Raja-Raja sebagai pelindung dan pengekal identiti dan cara hidup masyarakat Malaysia (MAIS, 2019). Dengan kewujudan jawatan YDPA yang diibaratkan sebagai wakil Allah di muka bumi, kedudukan raja-raja Melayu telah diangkat, demi memastikan seluruh bangsa dan agama dalam keadaan aman dan sejahtera. Jika wujud sebarang perbalahan dalam pentadbiran, YDPA berperanan penting sebagai kuasa besar di dalam negara untuk memperbetulkan keadaan itu.

Muhammad Shamsul (2019) menyoroti saling kebergantungan institusi rakyat dan institusi kerajaan dan menyatakan sejauh mana ketiadaan salah satu akan mewujudkan pemerintahan yang tidak lengkap. Penulis (Nazri, 2020; Muhammad Shamsul, 2019) menyebut bahawa penciptaan pemerintahan bermula dengan mempunyai pemerintah yang akan menentukan hala tuju negara. H.P Lee (2010) memetik katakata Profesor Harding yang mengatakan bahawa kelangsungan sistem persekutuan juga sebahagiannya bergantung pada pemeliharaan monarki kerana kedua-duanya saling terkait, dan usaha melumpuhkan kedua-duanya memerlukan tindakan dan perancangan yang mantap. Nazri (2020) turut mengulas bahawa institusi beraja ini di dalam menegakkan keadilan dan memaksimumkan perlindungan hak-hak rakyat, perlu melantik pegawai perkhidmatan awam tertinggi yang tidak berat sebelah dan mengutamakan perlindungan kepada masyarakat. Dalam menghuraikan fungsi Raja Berperlembagaan di dalam sesebuah negara, Choo Chin Thye (2005) mengemukakan bahawa kuasa Raja-raja tidak dihadkan kepada upacara rasmi dan tidak rasmi negara. Sebenarnya, ia adalah badan perlembagaan utama yang telah ditubuhkan oleh para pembuat perlembagaan sebagai aspek tambahan kepada tiga cabang asas pemerintahan iaitu legislatif, kehakiman dan eksekutif. Majlis Raja-Raja diwujudkan bertujuan untuk menjadi juruaudit tambahan perlembagaan. 
Penulis dalam menghuraikan pentingnya YDPA untuk menguasai proses pemilihan Perdana Menteri menyebut persepsi masyarakat mengenai perkara ini (Muslim \& Umar, 2017). Menurut penulisan ini, semua parti-parti politik mensasarkan keputusan berdasarkan sentimen dan pertimbangan parti, maka di sinilah YDPA harus memutuskan ketua pemerintah yang berkelayakan menurut acuan perlembagaan. Secara simbolik, YDPA bertindak sebagai kuasa yang berwibawa dan mempunyai kuasa perlembagaan untuk mengimbangi mana-mana calon Perdana Menteri yang terlalu bercita-cita tinggi (Muslim \& Umar, 2017). Ini memberi kuasa kepada raja dengan kekuatan yang dapat mengatasi batasan parlimen, tempat di mana Perdana Menteri meraih sokongan majoriti (Ramachandran dan et al, 2018).

Tulisan mengenai pengalaman rakyat Malaysia mengenai pelantikan Perdana Menteri memberi tumpuan kepada tafsiran ketetapan Perlembagaan yang telah membentuk konvensyen yang menjadikan ketua parti, pakatan, gabungan yang memperoleh suara majoriti akan dilantik sebagai Perdana Menteri (Faruqi, 2008). Mengulas berkaitan cadangan untuk mengubah konvensyen ini dengan cadangan di mana Perdana Menteri dilantik di kalangan ahli Dewan Rakyat yang non-partisan, Sun (2020) menganggapnya sebagai cadangan yang sangat berbahaya kerana menumpukan kekuasaan di tangan Perdana Menteri. Ini akan membawa kepada risiko penyalahgunaan kuasa dan kediktatoran. Dalam mendefinisikan pemerintahan perpaduan, Zainal (2020), mengatakan idea kerajaan perpaduan secara teorinya merupakan pemilihan anggota kabinet tanpa mengira latar parti mereka dan hanya berdasarkan kepakaran masing-masing. Semasa memecat Perdana Menteri, HP Lee (2017) sambil memetik tulisan Aziz Bari menyebut bahawa walaupun YDPA tidak mempunyai kuasa untuk memecat perdana menteri yang masih mendapat sokongan majoriti namun baginda mempunyai kuasa untuk memerintahkan Yang Dipertua Dewan Rakyat untuk membenarkan undi tidak percaya dilakukan semasa sidang Parlimen. Ini termasuk dalam bidang kuasa YDPA sebagai penjaga perlembagaan.

YDPA dan Raja-Raja Melayu hanya boleh menggunakan hak istimewa seperti yang diberikan oleh Perlembagaan Persekutuan secara khusus. Dengan kata lain, Perlembagaan Persekutuan dengan berkesan menghilangkan segala hak prerogatif common law yang wujud sebelum kemerdekaan dan menggantinya dengan hak prerogatif yang diperuntukkan oleh Perlembagaan Persekutuan (Choo Chin Thye, 2005). Dapat disimpulkan bahawa tujuan penggubal perlembagaan itu adalah untuk memastikan Majlis RajaRaja memainkan peranan substantif sebagai penjaga Perlembagaan Persekutuan, terutama dalam fungsi khas dan fungsi perundingan mereka, berbanding dengan peranan istiadat atau boneka semata-mata. (Choo Chin Thye, 2005)

Pada tahun 2012, Andrew Harding dalam tulisannya mengakui bahawa perkembangan baru-baru ini menunjukkan pemerintah Malaysia telah mengambil pendekatan yang lebih aktif dalam menangani isuisu berkaitan rakyat di Malaysia. Beberapa contoh yang dinyatakan adalah berkaitan menghalang pelampau agama. HP Lee (2017) dalam bukunya juga telah menyetujui perkembangan ini dan merujuk kepada beberapa kejadian di Malaysia di mana YDPA telah secara lisan memberi peringatan kepada eksekutif khususnya pemerintah mengenai skandal 1MDB dan mereka yang berhasrat untuk memupuk budaya Arab untuk menggantikan budaya Melayu. Kedua-dua tulisan Abdul Aziz Bari (2013) dan Syed Husin Ali (2014) bersetuju bahawa para penguasa menyedari perlunya mereka mempamerkan kekuatan mereka untuk menyesuaikan diri dengan perubahan dalam tafsiran perlembagaan moden.

Tambahan pula, Perlembagaan Persekutuan Malaysia sebagai undang-undang yang tertinggi di Malaysia, telah memperuntukkan Sistem Raja Berpelembagaan sebagai satu langkah yang proaktif untuk menonjolkan ketelusan institusi beraja di negara ini. Walaupun terdapat pelbagai Perkara yang menekankan kuasa kedaulatan Raja-Raja, namun, ada kalanya juga, kuasa itu melangkaui peruntukan di dalam Perlembagaan Persekutuan. Kedaulatan Raja-Raja yang melampaui peruntukan Perlembagaan Persekutuan boleh dikaitkan atas alasan legitimasi kewujudan sesebuah negeri dan sejarahnya berasaskan raja (Abdul Aziz, 2008). Perkara ini dapat dilihat melalui perjanjian di antara semua Sultan dan King George IV pada 15 Julai 1957 secara efektif telah melucutkan kuasa Sultan terhadap pentadbiran Tanah Melayu, yang sebelum ini Perlembagaan Persekutuan menjamin hak baginda dalam pelbagai bentuk. Sultan bukan sekadar simbol kedaulatan negara tetapi baginda juga merupakan ketua bagi ketiga-tiga cabang kerajaan (Tuanku Jaafar, 2018). Perlembagaan memberikan hak sebagai Ketua Eksekutif kepada YDPA dan juga merupakan satu daripada tiga bahagian Parlimen. YDPA juga dilihat sebagai ketua badan kehakiman kerana lantikan hakim-hakim adalah di bawah kuasa baginda (Tuanku Jaafar, 2018). 
Kuasa dan pengaruh sebenar Raja itu terletak pada diri dan institusi bukan pada peruntukan perlembagaan dan undang-undang yang bersifat yang lebih formal, Raja-Raja masih memiliki kuasa tersimpan (Hans Kelsen, 1986). Sebagai contoh, dalam pelbagai insiden merentas masa, telah terbukti campurtangan Raja-Raja memberikan kesan yang positif dalam menjaga kemaslahatan masyarakat seperti campurtangan Almarhum Sultan Abdul Halim dalam konflik pengekalan Candi Lembah Bujang (Syed Ahmad, 2019). Campur tangan Raja-Raja juga mampu meleraikan konflik dan percanggahan politik antara pelbagai kaum, seperti isu pelantikan Menteri Besar Perlis, Perak dan Terengganu (Jaafar, 2018). Institusi Raja-Raja Melayu juga adalah menjalankan fungsi menyemak dan menyeimbang kuasa kerajaan dan Perdana Menteri. Perkara ini dapat dilihat melalui beberapa konvensyen dan amalan yang sedia ada seperti Perdana Menteri datang mengadap YDPA dan memberikan laporan setiap hari Rabu pada setiap minggu (Syed Ahmad, 2019). Juga, Titah Baginda Sultan dan YDPA dihormati di setiap lapisan masyarakat, contohnya seperti titah YDPA sebagai Canselor pada Hari Pemasyuran sebagai Canselor UiTM telah memberikan punca kuasa kepada Kursi Institusi Raja-Raja Melayu untuk membangunkan modul bagi menyemai rasa kasih kepada Raja-Raja Melayu (Canselor UiTM, 2019).

Melalui kajian literatur di atas, didapati tiada penulisan atau kajian yang jelas mengenai sejauh manakah kedaulatan Raja-Raja Melayu boleh melangkaui peruntukan Perlembagaan Persekutuan serta implikasi terhadap masyarakat dan negara jika berlakunya tindakan Raja yang melampaui perlembagaan. Literatur mengenai bidang ini terutama tertumpu pada ruang lingkup dan had kuasa prerogatif YDPA. Walaupun beberapa pengarang bersetuju bahawa kuasa prerogatif perlembagaan YDPA adalah terhad kerana raja Malaysia adalah raja berperlembagaan dan perlembagaan memperuntukkan kuasa untuk bertindak berdasarkan nasihat, beberapa pengarang membuat tuntutan berani bahawa YDPA mempunyai kuasa yang melampaui bidang kuasa perlembagaan. Walaupun dilihat banyak unsur-unsur positif dalam hal ini, namun terdapat banyak persoalan yang belum terjawab, contohnya isu pertindihan kuasa di antara eksekutif, legislatif dan kehakiman atau timbulnya kekeliruan di kalangan masyarakat tentang kuasa Raja-Raja Melayu. Oleh sebab itulah, kajian ini dijalankan demi menganalisa implikasinya terhadap sistem Raja berperlembagaan di Malaysia.

\section{Metod Kajian}

Kajian ini menggunakan pendekatan kualitatif untuk pengumpulan bahan kajian doktrin. Data kajian doktrin tersebut diperoleh daripada sumber utama dan sekunder melalui penyelidikan berasaskan perpustakaan, berfokuskan kepada bahan perundangan, seperti keputusan kehakiman Malaysia, dan sebahagian besar kandungan pangkalan data dalam talian termasuk LexisNexis, Malayan Legal Journal, dan lain-lain. Beberapa kes undang-undang dan kerangka perundangan yang berkaitan dengan kuasa YDPA, Majlis Raja-Raja, Parlimen dan Perdana Menteri yang melibatkan peruntukan Perlembagaan Persekutuan Malaysia dan Akta Majlis Keselamatan Negara 2016, termasuklah pekeliling dan arahan turut dikumpul. Kajian ini mengkaji secara kritis semua literatur tentang peranan dan kekuatan Raja dalam menentukan Ketua Pemerintah dari pelbagai sumber termasuklah buku teks, jurnal artikel, laporan pemerintah, surat khabar dan sumber dalam talian. Kajian ini menulusuri latar belakang sejarah, ruang lingkup dan batasan kepada kuasa prerogatif ini dengan merujuk kepada Perlembagaan Persekutuan, laporan perjalanan kemerdekaan 1957, undang-undang yang relevan, pandangan ilmiah dan perbincangan akademik. Tafsiran mahkamah juga diteliti dan niat perundangan ketika pindaan dan pengesahan undang-undang baru dibuat berkaitan dengan kuasa ini.

Untuk mengkaji lebih mendalam tentang sistem monarki di Malaysia, model legalisme Lockean telah diteliti. Teori dan model sistem pemerintahan berkisar dari absolutisme hak tuhan (Bossuet, 1707), absolutisme falsafah (Hobbes, 1651), konstitusionalisme falsafah dan alkitabiah (Locke, 1689) hingga idea moden pertama mengenai pemisahan total kuasa (Montesquieu, 1748). Pengertian Locke mengenai pemisahan kuasa ditingkatkan dengan doktrin hak prerogatif. Pemahaman Locke mengenai kuasa prerogatif memberi sumbangan besar kepada penyelidikan mengenai kuasa monarki semasa kecemasan dan digunakan secara meluas sebagai kerangka teori dalam kajian prerogatif. Arnold (2005), Tushnet (2005), Jenkins (2011) dan Sharon (2019) secara kritis menekankan bahawa hak prerogatif Raja menurut Lockean akan memperkasakan kedudukan monarki di luar parameter undang-undang. Peruntukan Perlembagaan Persekutuan Malaysia dianalisis berdasarkan ciri utama Lockean iaitu pemisahan institusi, 
kuasa budi bicara eksekutif, hak istimewa penguasa, tujuan untuk kebaikan awam, penilaian awam dan kaedah ekstra-perlembagaan (Locke, 1988).

Bagi menguatkan dapatan kajian doktrin, wawancara berstruktur separa juga telah diadakan. Data yang diperoleh melalui kajian doktrin dianalisa bersama wawancara berstruktur separa dengan responden yang telah dipilih melalui tujuan pendekatan yang digunakan. Perbincangan asas juga telah dilakukan berdasarkan kepada pendekatan normatif dengan analisis kandungan penulisan berkaitan topik fungsi dan kuasa YDPA.

\section{Hasil Kajian}

Perkembangan sistem monarki di Malaysia telah berevolusi semenjak dari kerajaan Kesultanan Melaka kuno sehingga kini. Sejak tahun 80-an, kedudukan Raja-Raja telah dicabar oleh banyak konfrontasi (HP Lee, 1993; Raja Aziz Addruse, 1998). Namun, sistem monarki ini kekal berusaha untuk mendapatkan peranan dan kedudukannya di Malaysia selepas kemerdekaan pada tahun 1957, walaupun dengan kekuatan yang semakin berkurang. Sehingga kini, kewujudan dan peranannya terjamin dengan kewujudan beberapa Perkara dalam perlembagaan Malaysia, walaupun dengan kuasa yang terhad kepada monarki (Mohamad Mangsor et al., 2020).

Umum bersetuju bahawa konsep raja berperlembagaan adalah antara elemen di dalam Perlembagaan Malaysia. YDPA diberi kuasa budi bicara (Perkara 40 (1) dan 40 (1A) Perlembagaan Persekutuan) dan kuasa bukan budi bicara (Perkara 40 (2) Perlembagaan Persekutuan). Terdapat juga beberapa peruntukan yang membolehkan YDPA bertindak atas kuasa budi bicara sendiri tetapi tertakluk kepada peruntukan perlembagaan yang lain. Misalnya, pengisytiharan darurat, pelantikan Perdana Menteri dan pembubaran Dewan Rakyat berada di bawah kuasa prerogatif YDPA. Penggunaan kuasa budi bicara YDPA sendiri hanya menjadi perlembagaan setelah mendapat nasihat Perdana Menteri, Kabinet atau badan perundingan lain (Aziz Bari, 2003; Andrew Harding, 1996; Shad Saleem Faruqi, 2019). Namun begitu, kerap kali pelaksanaan kuasa hak prerogatif oleh YDPA ini dicabar atas dasar di luar konteks perlembagaan.

Penggunaan kuasa budi bicara harus difahami untuk memberi hak eksklusif kepada YDPA untuk membuat keputusan, namun kes-kes sebelum ini yang telah diputuskan oleh hakim-hakim Malaysia (Madhavan Nair lwn Pemerintahan Malaysia [1975] 2 MLJ 286, Teh Cheng Poh lwn Pendakwa Raya [1979] 1 MLJ 50; Balakrishnan lwn Ketua Pengarah Perkhidmatan Awam Malaysia dan Kerajaan Malaysia [1981] 2 MLJ 259) menunjukkan kuasa YDPA untuk membuat keputusan terhad kepada ketetapan perlembagaan. Walaupun Raja-Raja adalah ketua negara di peringkat persekutuan atau negeri, tetapi fungsinya terbatas dengan masih tertakluk kepada nasihat yang diterima daripada Jemaah Menteri (Aziz Bari, 2003).

Kedaulatan kuasa YDPA boleh dilihat melalui beberapa situasi yang berlaku masa kini. Sebagai contoh, tindakan YDPA dalam pelantikan Perdana Menteri berdasarkan kuasa termaktub di bawah Perkara 40 (2) (a) dan konsep raja berperlembagaan, dan harus dibaca bersama dengan Perkara 43 (2) (a) dan 43 (7). YDPA boleh menggunakan kuasa budi bicara untuk melantik individu yang mendapat sokongan majoriti di Dewan Rakyat sebagai Perdana Menteri, pada hemat baginda. Pelantikan itu seterusnya boleh membawa kepada pelantikan jawatan menteri tertinggi yang lain untuk pembentukan pemerintahan yang baik. Penggunaan kuasa ini dapat dianalisa melalui kes-kes di peringkat negeri sebelum ini, antaranya Stephen Kalong Ningkan (1966), Tun Datu Mustapha (1980), Dato Seri Nizar (2010), dan pelantikan Ketua Menteri Sabah (2020) yang diputuskan selari dengan peruntukan perlembagaan di peringkat persekutuan. Pengaplikasian kuasa ini dapat dilihat ketika isu pergolakan politik yang baru berlaku pada tahun 2020, telah menguji kuasa budi bicara YDPA. Pilihan Raya Umum ke-14 pada 10 Mei 2018 lalu telah mencipta sejarah negara buat kali pertama di Malaysia, menyaksikan kemenangan parti gabungan, Pakatan Harapan (PH) (yang terdiri daripada Bersatu, Amanah, Keadilan dan DAP) menjatuhkan kubu 62 tahun yang dipegang oleh parti Barisan Nasional (BN). Dengan memenangi 113 kerusi dan memperoleh majoriti sederhana (NST, 10 Mei 2018), PH memenuhi syarat untuk memperoleh suara majoriti dengan yakin dari anggota di Dewan Rakyat sehingga melayakkan wakil PH dilantik sebagai 
Perdana Menteri. Dimensi baru pelantikan Perdana Menteri berlaku ketika pemimpin gabungan PH menandatangani deklarasi berkanun yang membuat perjanjian mereka untuk mencalonkan Tun Mahathir sebulat suara sebagai Perdana Menteri. Sekali lagi menandakan lakaran sejarah baru ketika Tun Mahathir dilantik oleh YDPA untuk kali kedua sebagai Perdana Menteri Malaysia yang ke-7. Sejarah terus terukir apabila Tun Mahathir meletakkan jawatan pada bulan Februari 2020, maka YDPA di bawah seliaan Perkara 40 (2) (a) dan 43 (2) (a) sekali lagi perlu menyelesaikan masalah pelantikan Perdana Menteri yang baru. Dengan pengunduran Tun Mahathir, mandat yang diberikan oleh rakyat melalui pemilihan undi sepertinya telah dipinggirkan kerana undian mereka secara tidak langsung telah diabaikan dalam senario ini. Kemelut berakhir apabila Tan Sri Muhyiddin Yassin dilantik sebagai Perdana Menteri ke-8 pada 29 Feb 2020, menggunakan kuasa prerogatif YDPA (The Star, 29 Feb 2020).

Walaupun masalah peletakan jawatan Perdana Menteri ialah perkara pertama dalam sejarah negara, perlu ditegaskan bahawa perkara ini bukanlah perkara baru di peringkat negeri, seperti kes di Sarawak melibatkan Ketua Menteri Stephen Kalong Ningkam, Ketua Menteri Sabah Datu Amir Kahar and Tun Datu Mustapha and Menteri Besar Perak, Datuk Sri Mohamad Nizar (Mohamad Mangsor et al., 2020). Melihat kepada senario yang berlaku semasa wabak pandemik Covid-19, YDPA memerlukan pertimbangan yang teliti kerana perkara itu boleh mendedahkan negara kepada kerusuhan politik yang lebih meluas dan pemerintahan yang tidak stabil serta membawa kesan buruk kejatuhan ekonomi Malaysia, yang juga dipengaruhi oleh Perintah Kawalan Pergerakan (PKP) (Abdul Aziz et al., 2020). Dalam pelantikan Perdana Menteri ke-8, YDPA telah menggunakan kaedah yang sebelumnya telah digunakan oleh Sultan Perak pada tahun 2009 dalam memutuskan penghitungan sokongan majoriti sebenar untuk Menteri Besar Perak ketika itu. Menurut Faruqi (2020), kuasa YDPA dalam melantik Ketua Pemerintah sangat menuntut kebijaksanaan baginda. Sebagai individu utama dalam Perlembagaan, Raja mempunyai kuasa untuk membuat keputusan penting bukan sahaja menurut Perlembagaan tetapi juga menurut Akta Parlimen (Muslim, 2013). Walaupun kekuasaan ketua negara terbatas dalam menjalankan fungsi eksekutifnya, namun Raja masih mendominasi dalam pemilihan ketua pemerintah.

Selain itu, terdapat beberapa situasi yang telah terjadi semasa pergolakan politik di Malaysia sedang berlaku, menjadikan peranan YDPA sangat dititikberatkan. Melompat parti, antaranya, yang diperakui di bawah Perkara 10 (1)(c) Perlembagaan Persekutuan sangat banyak dan biasa berlaku dalam kalangan ahli politik. Dalam kes Nordin Salleh (1992), hanya Parlimen mempunyai bidang kuasa yang membataskan hak kebebasan melompat parti. Tidak ada undang-undang persekutuan yang diperkenalkan untuk mengehadkan parti. Sebagai contoh, di Melaka, dua individu dari PKR dan DAP membenarkan peralihan pakatan dari kerajaan Negeri yang dikuasai PH kepada BN (Leong, 2020). Anggota perundangan Kedah pula berkumpul di belakang bekas Menteri Besar untuk mengekalkan 'status quo' tetapi tidak berjaya. Dalam keadaan ini, YDPA atau Raja-Raja dalam menjalankan kuasa budi bicara mereka boleh mempertimbangkan 'undi rasmi tanpa keyakinan' jika Dewan Rakyat atau DUN sedang bersidang. YDPA juga dapat menentukan keyakinan Dewan dengan mengadakan pertemuan dengan anggota Parlimen. Ini dilaksanakan semasa krisis Perak 2009 dan keadaan politik Malaysia pada tahun 2020. Selain itu, Parlimen juga diumumkan untuk digantung daripada beroperasi seperti biasa, menjadikan Perikatan Nasional dan Tan Sri Muhyiddin Yassin sebagai Perdana Menteri telah menimbulkan krisis politik yang sangat hebat (The Star, 2021). Insiden ini mengakibatkan penurunan majoriti Perikatan di Parlimen dari 111 hingga 110 dan mewujudkan Parlimen yang digantung. Setelah majoriti terhakis, budi bicara YPDA mula mengambil peranannya (Faruqi, 2020; Mohamad Mangsor, 2020). Perkara 55 (4) membenarkan tempoh masa selama 60 hari tanpa Parlimen diantara pembubaran dan Pilihanraya Umum dan 120 hari berlalu antara pembubaran dan pertemuan pertama parlimen baru. Walaupun terlalu banyak konflik yang terjadi, namun pilihan raya umum secara segera tetap tidak boleh dilaksanakan kerana berkemungkinan besar menjejaskan tahap kesihatan hidup rakyat Malaysia pada musim pandemik ini.

Di samping itu, YDPA juga berperanan untuk mengisytiharkan proklamasi darurat dalam menjalankan kuasa kedaulatan baginda. Perkara 150 membolehkan berlakunya undang-undang darurat dan boleh melangkaui prosedur perundangan biasa walaupun dibuat dengan cepat dan tidak selari dengan ketentuan Perlembagaan. Sebagai contoh, semasa pergolakan politik berlaku, YDPA dibenarkan untuk menangguhkan pemilihan kerajaan baru lebih dari jangka masa yang ditetapkan dalam perlembagaan. 
Ini dapat dilihat dalam Deklarasi Darurat 1969 yang mencatatkan tempoh dua tahun tanpa kerajaan dibentuk. Berikutan itu, pengisytiharan darurat di Batu Sapi Sabah (berikutan kematian Ahli Parlimennya) dibuat. Walaupun begitu, pelaksanaan kuasa oleh YDPA di bawah peruntukan ini tertakluk kepada penafsiran yang boleh mengkategorikan kuasa ini di bawah kuasa YDPA berdasarkan budi bicara atau bukan budi bicara (Abdul Aziz et al., 2020). Selepas kes Stephen Kalong Ningkan yang berlaku pada tahun 1967, kuasa ini selalu diterima sebagai kuasa bukan budi bicara yang mengaitkannya dengan konsep raja berperlembagaan yang harus dilakukan oleh YDPA ketika menjalankan kuasanya perlu bertindak atas nasihat kecuali dinyatakan dengan jelas dalam peruntukan kuasa adalah hak istimewa Raja. Walaupun penafsiran literal yang diberikan di bawah Perkara 150 (1) tentang adanya 'darurat serius' hanya boleh dilakukan apabila terdapat ancaman terhadap keamanan, atau kehidupan ekonomi atau ketertiban umum, tetapi ketentuan ini boleh dipanjangkan dan aplikasinya dapat dilihat ketika pengisytiharan darurat dibuat di Sarawak pada tahun 1966 berikutan pemecatan Menteri Besarnya, Stephen Kalong Ningkan. Skop 'darurat serius' dan ancaman terhadap keamanan, atau kehidupan ekonomi atau ketenteraman awam kemudian diberi pandangan yang lebih luas melalui keputusan yang dibuat dalam PP lwn Johnson Tan Han Seng [1977] yang telah memperluas konsep untuk memasukkan perang, kebuluran, gempa bumi, banjir, wabak dan keruntuhan kerajaan sivil.

Pengistiharan darurat yang diberikan oleh YDPA sebenarnya telah berkembang sejak dahulu lagi, terutama dari aspek darurat alam sekitar. Terdapat perbincangan mengenai keperluan untuk mengisytiharkan darurat, antaranya semasa banjir besar yang telah melumpuhkan pentadbiran daerah yang terjejas di Kelantan pada tahun 2014, kejatuhan mata wang Malaysia yang tidak dapat dielakkan pada tahun 2015, di Kuala Selangor dan Pelabuhan Klang pada tahun 2005 serta di Muar dan Ledang pada tahun 2013 kerana keadaan jerebu yang teruk mencerminkan pendekatan yang berbeza untuk menangani keadaan darurat bencana (Abdul Aziz et al., 2020). Para penyelidik berpendapat bahawa pengisytiharan darurat boleh dibuat juga terhadap bencana-bencana kontemporeri yang telah terjadi beberapa tahun kebelakangan ini. Antaranya, pencemaran alam sekitar yang teruk yang mempengaruhi daerah Pasir Gudang, Johor. Pada tahun 2019, insiden pembuangan kimia di Sungai Kim Kim menyebabkan Dewan Rakyat meluluskan usul untuk mengisytiharkan keadaan darurat (Devi, 2019) tetapi Eksekutif menolak permohonan tersebut (Annuar, 2019). Dalam hal ini, Mohamad Mangsor et al. (2021) menampilkan Teori Lockean yang menekankan kuasa budi bicara tertentu yang diberikan kepada Eksekutif jika negara mengamalkan pemisahan institusi antara Badan Perundangan dan Eksekutif. Di samping itu, kuasa budi bicara dapat dilaksanakan "di luar batas undang-undang" (Locke, 1988). Bagaimanapun, Parlimen Malaysia terdiri dari Badan Perundangan bersama dengan Eksekutif yang cenderung untuk menguasai proses perundangan. Malaysia mengadaptasi struktur poliarki (raja di Parlimen) yang merupakan bekas sistem Inggeris sebelum British berubah menjadi kedaulatan parlimen mutlak atau rejim monokrat. Risalah Kedua Locke menetapkan bahawa sistem monokrat adalah kuasa prerogatif raja "bertentangan dan di luar undang-undang" untuk melindungi salus populi dan perintah perlembagaan (Pasquino, 1998). Kejadian ini mungkin berlaku kerana kurangnya garis panduan yang lebih jelas untuk mengisytiharkan darurat oleh Eksekutif menurut Lockean "salus populi supreme lex" (Locke, 1988).

\section{Perbincangan Kajian}

Malaysia mengamalkan raja berperlembagaan dalam sistem demokrasi berparlimen (Bulmer, 2017). Walaupun ia memiliki struktur bicameral di peringkat persekutuan iaitu YDPA sebagai ketua negara dan Perdana Menteri sebagai ketua pemerintah, komposisi peringkat negeri ialah sistem unicameral dengan Raja sebagai ketua negara manakala Ketua Menteri (Menteri Besar) sebagai ketua kerajaan negeri. Raja negeri dikenali sebagai Sultan, Raja atau Yang di-Pertuan Besar dan negeri-negeri tanpa pemerintah akan melantik Yang di-Pertua Negeri (The Star, 2010). Berdasarkan sistem ini, Raja-Raja bagi negeri-negeri bertindak atas nasihat Majlis Eksekutif yang diketuai oleh Menteri Besar. Sementara di peringkat Persekutuan, YDPA bertindak atas nasihat Jemaah Menteri yang diketuai oleh Perdana Menteri dalam semua perkara kecuali dalam beberapa perkara yang disebut sebagai kuasa budi bicara. 
Sistem kesultanan adalah sistem monokrat dengan pemerintah di setiap negeri sehinggalah Inggeris menjadikan Malaysia sebagai persekutuan. Draf pertama perlembagaan Malaysia pada tahun 1956 melemahkan kuasa Raja-Raja Melayu yang menyebabkan mereka menuntut pindaan untuk mentakrifkan semula fungsi dan kedudukan mereka dalam pemerintahan negeri termasuklah isu-isu kepentingan nasional (Fernando, 2014). Institusi kerajaan yang dikenali sebagai 'Persidangan Majlis Raja-Raja Melayu' ini memainkan peranan penting dalam menyatukan pemerintah dan kerajaan, sekaligus memastikan negara di dalam landasan yang betul. Raja dipilih melalui majlis ini dengan menggunakan asas putaran antara pemerintah negeri di Semenanjung Malaysia (Mohamad Mangsor et al., 2021). Persidangan Majlis Raja-Raja Melayu adalah sebahagian dari Eksekutif dan salah satu sistem monarki tertua dan unik, yang telah muncul dan bertahan dari kerajaan Melaka hingga kini. Peranan mereka dalam hal-hal kecemasan adalah konsultatif dalam bentuk nasihat, berhati-hati dan memberi amaran yang berkaitan dengan persoalan dasar nasional (Phang Chin Hock, 1980). Hal-hal yang berkaitan dengan persidangan memerlukan persetujuan mereka ketika berkaitan dengan perubahan batas negara (Perkara 2 (b)), hak-hak Raja (Perkara 38 (4)) dan sembilan topik dalam Perkara 159 (5) Perlembagaan Persekutuan. Persidangan Majlis Raja-Raja Melayu tersebut dapat meningkatkan dan memperkuat fungsi YDPA dengan mempertimbangkan hal-hal lain yang difikirkannya sesuai dan dapat memberi nasihat, pandangan dan peringatan tentang isu-isu yang berkaitan dengan krisis alam sekitar di bawah Perkara 38 (2).

Menurut Mahkamah Persekutuan dalam kes Dato Seri Anwar bin Ibrahim v Perdana Menteri Malaysia \& Anor [2010] 3 MLJ 174, hakim berpendapat bahawa Perkara 40 membahagikan fungsi Raja kepada dua kategori yang berbeza iaitu fungsi yang boleh dilaksanakannya mengikut budi bicaranya dan kedua, baginda mesti menjalankan atau bertindak sesuai dengan nasihat menteri. Dengan kata lain, fungsi yang dilaksanakan oleh baginda di bawah Perlembagaan atau undang-undang persekutuan akan dilaksanakan sesuai dengan nasihat Kabinet atau Menteri yang bertindak di bawah kuasa umum Kabinet. Rujukan yang dibawa kepada YDPA hanyalah sekadar formaliti di bawah sistem YDPA sebagai raja berperlembagaan (Halsbury). Dalam mengupas fungsi perlembagaan raja, Choo Chin Thye (2005) berpendapat bahawa Raja-Raja tidak dimaksudkan hanya sekadar bersifat adat istiadat dan formal. Sebenarnya, Raja-Raja adalah badan perlembagaan utama yang dirangka oleh perlembagaan persekutuan sebagai aspek tambahan kepada tiga cabang asas pemerintahan di negara ini, menjadikan proses semak dan imbang semakin telus.

Namun begitu, kuasa YDPA khususnya dalam pelantikan Perdana Menteri selalu dipersoal atas dasar melangkaui perlembagaan. Perkara 40 (2)(a), yang memberikan kuasa kepada YDPA harus disertakan dengan Perkara 43 (2) (a) dan 43 (7) untuk memastikan tindakan YDPA selari dengan perlembagaan. Walaupun kata budi bicara secara umum dapat ditafsirkan untuk memberikan kuasa yang luas kepada YDPA dalam memilih Perdana Menteri pilihannya, tetapi sebagai raja berperlembagaan, kuasanya terbatas pada memilih orang yang layak menjadi Perdana Menteri yang dibahaskan dalam perlembagaan. Gabungan kedua-dua perkara ini dapat difahami seperti berikut dan perbincangan sebelumnya akan berdasarkan rajah 1 .

Dalam hal ini, YDPA boleh menggunakan kuasa budi bicara untuk melantik individu yang baginda percaya pada hematnya, mendapat sokongan majoriti di Dewan Rakyat sebagai Perdana Menteri. 'Keyakinan majoriti anggota Dewan' bukanlah masalah subjektif atau abstrak semata-mata, namun ianya merujuk kepada bukti kerusi dan suara yang dapat disahkan di Dewan. Ungkapan 'dalam penilaiannya' kemungkinan akan mendapat kepercayaan majoriti bermaksud bahawa YDPA mesti berpuas hati bahawa calon yang berpotensi cenderung mendapat sokongan majoriti anggota Dewan Perwakilan Rakyat (Dewan Rakyat). Dalam keadaan sebegini, YDPA harus bijak menggunakan budi bicaranya supaya pelantikan yang penting sebegitu mengikut peruntukan undang-undang yang sedia ada (Abdul Aziz et al., 2020). Menariknya, sehingga sekarang, tidak ada lagi syarat mengatakan bahawa hanya orang Melayu atau Muslim boleh menjadi Perdana Menteri. Namun, semua Perdana Menteri yang dilantik selama ini bermula daripada Tunku Abdul Rahman sehingga sekarang iaitu Tan Sri Muhyiddin Yassin, mereka semua berbangsa Melayu dan beragama Islam. Amalan ini sebenarnya merupakan konvensyen perlembagaan yang sudah termeterai tetapi masih tertakluk kepada Artikel 8 Perlembagaan Persekutuan (Mohamad Mangsor et al., 2020). Secara ringkasnya, tidak dinafikan bahawa kesan daripada pelantikan Perdana Menteri yang baru berlaku di negara Malaysia, berserta pembubaran parlimen, isu lompat parti 
dan parlimen gantung, sangat membuka mata rakyat jelata tentang kepentingan sistem Raja Berpelembagaan sekaligus mengakui akan tanggungjawab baginda sebagai Ketua Tertinggi Negara memastikan negara aman dan stabil.

Gambarajah 1: Kuasa prerogatif YDPA untuk melantik Perdana Menteri dalam ruang lingkup Raja Berperlembagaan - Perkara 40 (2)(a)

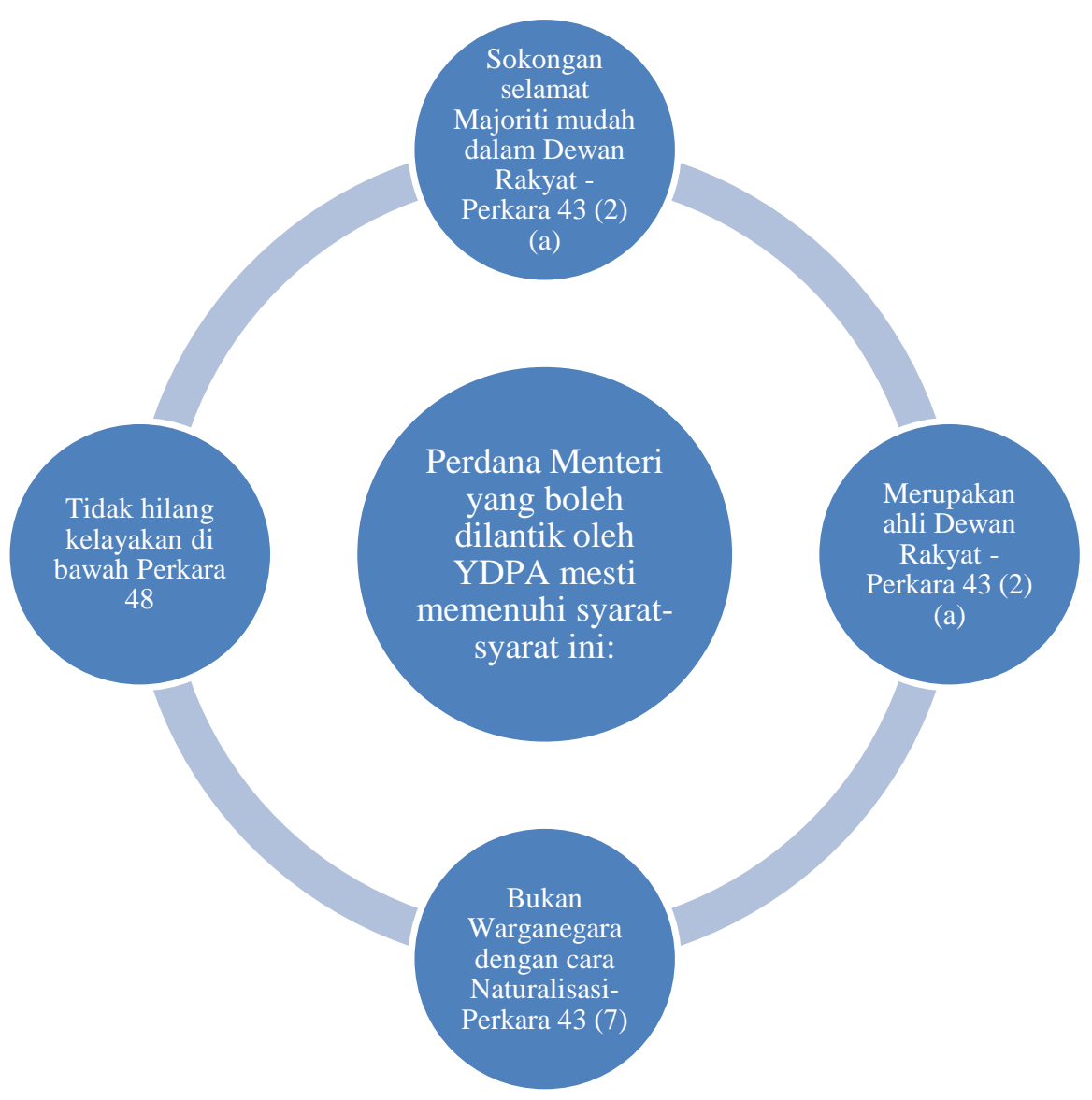

Sumber: Abdul Aziz et al. (2020)

Bagi skop perbincangan isu darurat, penulis berpendapat bahawa kesan daripada pergolakan politik yang berlaku telah menyebabkan pengishtiharan darurat menjadi suatu keperluan dalam situasi sebegitu. Keadaan darurat ialah satu deklarasi penting dari YDPA supaya dapat menangguhkan beberapa fungsi normal dari kuasa eksekutif, perundangan dan kehakiman, sekaligus memberi amaran kepada rakyat untuk mengubah tingkah laku normal mereka, atau memerintahkan agensi pemerintah untuk melaksanakan rancangan kesiapsiagaan darurat. Ini juga dapat digunakan sebagai alasan untuk menangguhkan hak dan kebebasan, walaupun ada dijamin di bawah perlembagaan. Pengisytiharan seperti itu biasanya datang pada waktu bencana alam atau buatan manusia, atau setelah pengisytiharan perang. Sebelum ini juga, terdapat beberapa peraturan darurat telah diumumkan dan digunakan sejak tahun 1969. Peraturan-peraturan ini memberikan kuasa yang luas kepada polis dan pemerintah, contohnya seseorang boleh ditahan tanpa perbicaraan dan dibuang ke kawasan tertentu. Dalam hal ini, Mohamad Mangsor et al., (2021) telah membahaskan konsep teori Lockean, dan pemakaiannya di dalam konteks Perlembagaan Persekutuan Malaysia.

Jadual 1 menunjukkan bahawa teori Lockean menekankan kuasa budi bicara tertentu yang diberikan kepada Eksekutif. Bagaimanapun, Parlimen di Malaysia yang terdiri dari Badan Perundangan dan Eksekutif, Eksekutif telah cenderung untuk menguasai proses perundangan. Lockean menekankan bahawa kuasa Eksekutif yang diberikan kepada pemerintah adalah semata-mata untuk kepentingan masyarakat dan mesti dilaksanakan oleh undang-undang yang digubal tanpa pengecualian (Locke, 1988). Kuasa prerogatif setara dengan kawalan budi bicara untuk memutuskan perkara-perkara kebaikan awam 
di luar parameter undang-undang (Locke, 1988). Namun, hak prerogatif pemerintah tidak boleh mengganti undang-undang dengan kehendak raja. Kediktatoran hak prerogatif atas dasar kerajaan mesti dibezakan dengan penolakan untuk memberikan keputusan untuk kebaikan rakyat. Kesahihan kuasa budi bicara terbatas dalam kerangka kepentingan awam dan penentangan atas dasar ini dibenarkan (Locke, 1988). Di Malaysia pula, kuasa hak prerogatif termaktub dalam perlembagaan. Peruntukan ini merangkumi ungkapan "keadaan darurat yang teruk di mana keselamatan, atau kehidupan ekonomi, atau ketenteraman awam di Persekutuan atau mana-mana bahagiannya terancam".

Jadual 1: Penerapan Model Lockean

\begin{tabular}{cll}
\hline No & \multicolumn{1}{c}{ Kandungan Lockean } & \multicolumn{1}{c}{ Kedudukan Malaysia } \\
\hline $\mathbf{1}$ & Pemisahan Institusi & $\begin{array}{l}\text { Eksekutif adalah sebahagian daripada Badan } \\
\text { Perundangan }\end{array}$ \\
$\mathbf{2}$ & Kuasa budi bicara eksekutif & Perkara 40 (2), Perkara 40 (1) dan Perkara 40 \\
& & $(1 \mathrm{~A})$ \\
$\mathbf{3}$ & Kuasa prerogatif Raja & Perkara 150(1), Perkara 38(2), Perkara 130 \\
$\mathbf{4}$ & Bertujuan untuk kebaikan awam & Perkara 150(1) \\
$\mathbf{5}$ & Penilaian Awam & Ahli Dewan Parlimen \\
$\mathbf{6}$ & Kaedah ekstra-perlembagaan & Disekat oleh Perkara 4(1) \\
\hline
\end{tabular}

Sumber: Mohamad Mangsor et al. (2021)

Selain itu, Jadual 1 juga menunjukkan sisi positif teori Lockean, kerana membolehkan penilaian orang ramai (Locke, 1988). Ini memberikan perlindungan politik dan institusi terhadap penyalahgunaan kuasa (Sharon, 2019). Penglibatan masyarakat tempatan memainkan peranan penting dalam "melindungi masyarakat dari bahaya dan meminimumkan kerentanan mereka terhadap risiko bencana" (Zubir \& Amirrol, 2011). Namun begitu, aspek ini kurang diaplikasikan Malaysia melainkan jika anggota Parlimen atau Dewan Perwakilan dianggap sebagai wakil rakyat dan mengaitkan penilaian masyarakat. Misalnya, persetujuan usul oleh Dewan Rakyat tentang kejadian pembuangan kimia Sungai Kim Kim mungkin mewakili suara rakyat tetapi ditolak oleh pemerintah, akibat daripada kurangnya kefahaman tentang pelaksanaan darurat. Walaupun terdapat pengisytiharan darurat berdasarkan keselamatan nasional dan alasan politik, sebenarnya beberapa kes persekitaran dan bencana iklim dan wabak penyakit juga berjaya memproklamasikan darurat di Malaysia, seperti kes jerebu di Kuala Selangor dan Port Klang pada tahun 2005, dan kes wabak pandemik Covid19 pada tahun 2020 dan 2021. Hanya pada tahun 2019, permohonan darurat untuk pencemaran Sungai Kim Kim oleh Badan Perundangan telah ditolak oleh Eksekutif, yang terdiri daripad YDPA. (Mohamad Mangsor, 2020).

Satu lagi ciri Lockean yang dinyatakan dalam Jadual 1 ialah penyertaan orang ramai melibatkan keutamaan kuasa darurat digunakan secara ekstra-perlembagaan dan orang ramai memahami tindakan yang luar biasa dan menerima kedudukan dan normalisasi tersebut selaras dengan Perlembagaan (Tushnet, 2005). Namun begitu, aspek ini terbatas di Malaysia kerana Perlembagaan Persekutuan memperuntukkan Perkara 4(1) sebagai undang-undang tertinggi di Malaysia. Dengan menerapkan model legalisme Lockean, penulis berpendapat bahawa YDPA dapat melihat ketentuan Perkara 150(1) sebagai kuasa budi bicara baginda untuk bertindak di luar skop perlembagaan sebagai perkara luar biasa.

Secara keseluruhannya, pengisytiharan darurat itu perlulah mengambil kira dari sisi tentera dan polis yang pasti menjadi lebih banyak tanggungjawab yang perlu dilaksanakan untuk mengawal keadaan tersebut, sehingga kemampuan untuk melindungi penduduk akan berkurangan. Keadaan darurat akan terus berlangsung selagi mana tidak dibatalkan oleh YDPA atau kedua-dua Dewan di Parlimen (Mohamad Mangsor et al., 2020). Jadi, merujuk kepada teori Lockean, Raja-Raja boleh mula bertindak berdasarkan sifat ekstra-perlembagaan. Oleh itu, langkah yang dicadangkan ialah interpretasi kehakiman dari Perkara 40 (2) dan Perkara 130 dapat diperluaskan untuk memberi kuasa kepada YDPA dalam konteks ini. 


\section{Kesimpulan}

Sistem Raja Berpelembagaan di Malaysia merupakan satu sistem yang sangat unik, dan antara yang paling lama diamalkan di dunia. Kewujudan Raja-Raja Melayu semenjak zaman pemerintahan Kesultanan Melayu Melaka sehingga kini, masih kekal melaksanakan tanggungjawab di bawah lembayung perlembagaan persekutuan. Walaupun YDPA merupakan ketua negara, namun baginda masih lagi tertakluk kepada keluhuran perlembagaan. Persoalan tentang isu YDPA di bawah sistem raja berperlembagaan memegang kuasa terhad dalam pentadbiran negara, kini sudah dibuktikan dengan beberapa kemelut penting yang berlaku di Malaysia, terutamanya melibatkan pelantikan Perdana Menteri ke-7 dan ke-8. Isu konflik yang timbul diantara ahli politik, YDPA juga yang mendominasi keputusan akhir untuk memutuskan siapa yang layak memegang posisi tersebut. Dalam melaksanakan peranan ini, YDPA tidak mempunyai kuasa budi bicara yang tidak terbatas dan peribadi untuk memutuskan tetapi tertakluk kepada dua syarat utama bahawa calon mesti menjadi anggota Dewan Rakyat dan menikmati kepercayaan majoriti anggota Dewan Perwakilan. Insiden ini menunjukkan keperluan perlembagaan, seterusnya membuktikan kedaulatan raja-raja melayu masih berada di tahap yang tertinggi. Rakyat tidak boleh menafikan peranan YDPA ini kerana pasti boleh menyebabkan kepincangan tadbir urus negara. Selain itu, kedaulatan YDPA terus diterjemahkan melalui isu darurat yang timbul berkaitan dengan kesihatan dan keadaan alam sekitar, juga memperlihatkan kuasa YDPA dalam melaksanakan peranannya yang tertulis di dalam perlembagaan persekutuan. Kajian ini secara kritis menganalisis peranan penting YDPA dalam menyatakan proklamasi darurat untuk melindungi keselamatan rakyat dalam konteks lingkungan dan lingkungan iklim. Penyelidikan menggunakan mekanisme teori Lockean dalam memahami kekuatan untuk menyatakan darurat dalam krisis alam sekitar, mengetengahkan enam ciri penting, iaitu pemisahan institusi, kuasa budi bicara eksekutif, hak prerogatif penguasa, tujuan untuk kebaikan umum, penilaian awam dan sifat perlembagaan menguatkan lagi ciri kedaulatan YDPA terhadap perlembagaan undang-undang.

Kajian ini berjaya menerangkan kepada masyarakat dan kerajaan betapa pentingnya kedaulatan RajaRaja Melayu di bawah Perlembagaan Persekutuan. Terdapat beberapa situasi di mana Raja-Raja Melayu boleh menggunakan budi bicara untuk membuat sesuatu keputusan walaupun tidak termaktub di bawah Perlembagaan Persekutuan. Semuanya adalah untuk kemaslahatan dan kesejahteraan masyarakat dan negara. Menjadi antara negara demokrasi berparlimen, konsep raja berpelembagaan dan sistem monarki sangat penting untuk difahami supaya negar terus stabil diperintah oleh YDPA. Penyelidikan ini diharapkan dapat memberi sumbangan kepada cabang pengetahuan untuk meningkatkan kekuatan prerogatif YDPA berkaitan dengan keadaan darurat. Penerapan ciri-ciri teori Lockean dalam menafsirkan kuasa Eksekutif yang luas diharapkan dapat memberi pencerahan kepada peranan YDPA untuk menentukan keadaan darurat termasuklah menyatakan kecemasan termasuk semasa dalam isu pencemaran. Perkara 40(2) memberikan kekuatan budi bicara tersirat bagi YDPA untuk bertindak atas pertimbangannya sendiri. Kedaulatan Raja Raja Melayu dapat meningkatkan dan memperkuat fungsi YDPA dengan mempertimbangkan hal-hal lain yang difikirkannya sesuai dan dapat memberi nasihat, peringatan dan peringatan mengenai isu-isu yang berkaitan di bawah Perkara 38(2). Juga, kajian ini memberi signifikan terhadap kuasa YDPA yang dibatasi oleh perlembagaan Persekutuan, namun skop kuasa hak prerogatif baginda sebenarnya lebih luas terutama pada waktu darurat. Hasil kajian ini dapat membantu pemerintah, pembuat polisi, dan pihak berkepentingan untuk melihat ruang untuk reformasi dalam ruang lingkup kuasa prerogatif ini demi memastikan demokrasi raja berpelembagaan dapat terus dilestarikan di Malaysia.

\section{Rujukan}

Abdul Aziz, N., Mohamad Mangsor, M., Rahmat, N. E., Ristawati R., \& Zainudin, A. H. (2020). Preserving Rights to Life of The People within the Clashes of Two Crisis: Unlocking The Malaysian Ruler's Prerogative Power. International Journal of Law, Government and Communication (IJLGC)

Addruse, R. A. (1998, April 11). Police cannot assume the roles of judges. The New Straits Times. Retrieve from https://www.nst.com.my/ 
Malaysian Journal of Social Sciences and Humanities (MJSSH), Volume 6, Issue 8, (page 1 - 14), 2021

DOI: https://doi.org/10.47405/mjssh.v6i8.969

Annuar, A. (2019, March 14). Putrajaya not declaring emergency over Pasir Gudang toxic fumes. The Malay Mail.

Arnold, K. (2005). Domestic War: Locke's Concept of Prerogative and Implications for U.S. 'Wars' Today. Polity, 1-28.

Bari, A.A. (2003). The Malaysian Constitution-A Critical Introduction. Kuala Lumpur: Other Press.

Bari, A.A. (2008). The Monarchy: Symbolism, Guardianship and Stability. Dalam Syed Arabi Idid (Ed.), Malaysia at 50 Achievement \& Aspiration, Kuala Lumpur: Thomson Learning.

Bossuet, J. B. (1707). Bossuet: Politics Drawn from the Very Words of Holy Scripture. In Riley, P. (1990). Cambridge Texts in the History of Political Thought. Cambridge, UK: Cambridge University Press.

Bulmer, E. (2017). Constitutional Monarchs in Parliamentary Democracies. International Institute for Democracy and Electoral Assistance (International IDEA). https://www.idea.int/sites/default/files/publications/constitutional-monarchs-in-parliamentarydemocracies-primer.pdf.

Curzon, L. B. (2007). Dictionary of Law (Edisi ke-6). Kuala Lumpur: International Law Book Services.

Devi, V. (2019, July 17). Sg Kim Kim victims file RM30mil suit against Federal, state governments and 10 others. The Star.

Faruqi, S. S. (2020, March 26). Appointment of A Prime Minister - No. 3 of a Series of Essays by The Tun Hussein Onn Chair in International Studies. ISIS, Malaysia. Retrieved from https://www.isis.org.my/2020/03/26/appointment-of-a-prime-minister-no-3-of-a-series-of-essaysby-the-tun-hussein-onn-chair-in-international-studies/

Greenberg, D. (2012). Stroud's Judicial Dictionary of Words and Phrases.

Halsbury Laws of Malaysia-Constitutional Law vol 3(3)

Hanis Zainal, (April 24,2017), The Role of the Yang Di Pertuan Agung, The Star https://www.thestar.com.my/news/nation/2017/04/24/the-role-of-the-yang-dipertuan-agong/

Harding, A. (1996). Law, Government, and the Constitution in Malaysia. The Hague : London: Kluwer Law International.

Immanuel, W. (2004). World-Systems Analysis: An introduction. Durham: Duke University Press.

Jenkins, D. (2011). The Lockean Constitution: Separation of Powers and the Limits of Prerogative, 56 (3). McGill 543. https://id.erudit.org/iderudit/1005132ar.

Joseph M. Fernando. (2014). Defending the monarchy: The Malay rulers and the making of the Malayan constitution, 1956-1957, VARIA (88), 149-157

Leong, T. (2020, March 4). Johor, Melaka assemblies change sides. The Straits Times. https://www.straitstimes.com/asia/se-asia/johor-melaka-assemblies-change-sides

Lloyd, S. (1992). Hobbes's absolutism. In Ideals as Interests in Hobbes's Leviathan: The Power of Mind over Matter, 289-321. Cambridge: Cambridge University Press.

Locke, J. (1988). Two Treatises of Government, § 136. In Laslett, P. (1988). Cambridge Texts in the History of Political Thought, 265-428. Cambridge, UK: Cambridge University Press.

Majlis Agama Islam Negeri Selangor (MAIS) (2019). Kepentingan Mendaulatkan Institusi Beraja Di Malaysia dihttp://www.mais.gov.my/info mais/informasi/penerbitan/daulattuanku pada 25 Februari 2019

Mangsor, M. M., Aziz, N. A., Rahmat, N. E. \& Zainudin, A. H. (2021). Modelling Lockean Legalism in the Executive Emergency Power on Environment and Climate Change Domain in Malaysia. International Journal of Academic Research in Business and Social Sciences, 11 (5), 774-784.

Mohamad Mangsor, M., Abdul Aziz, N., Rahmat, N. E. \& Zainudin, A. H. (2020, June 27-28). The Role of Malaysian Monarch in Dominating the Decision of Dewan Rakyat to Appoint the Head of Government in Malaysia [Paper Presentation]. International Conference on Social Science and Technology for Postgraduates and Researchers (ICSSTPR2020), Perak, Malaysia.

Montesquieu, C.L.S. (1748). Montesquieu: The Spirit of the Laws. In Cohler, A. M., Miller, B.C. and Stone, H.S. (1989). Cambridge Texts in the History of Political Thought. Cambridge, UK: Cambridge University Press.

Muslim, N., Wan Hassan, W. Z. \& Umar, A. (2013). The Role of the Malay Royal Institutions According to the Constitution in Safeguarding Malay Position from the Higher Education Perspective. International Journal of Humanities and Social Science vol.3(13) : 267-274

Pasquino, P. (1998). Locke on King's Prerogative, Pol. Theory, 26, 198-208. 
Raja Azlan Shah. (1982). The Role of Constitutional Rulers: A Malaysia Perspective for the Laity", 1 Journal of Malaysian and Comparative Law, an article published in HP Lee(2017). Constitutional Conflicts in Contemporary Malaysia $2^{\text {nd }}$ Edn.( UK: Oxford University Press: 2017).

Raja Melayu Uitm Bersama Tan Sri Syed Danial Syed Ahmad, 2019 di Pejabat Penyimpan Mohor Besar Raja-Raja Pada 25 Julai 2019.

Saleem Faruqi, S. (2019). Our Constitution.Kuala Lumpur: Sweet \& Maxwell.

Sharon, A. (2019). Locke, liberty, and law: Legalism and extra-legal powers in the Second Treatise. European Journal of Political Theory.

The New Straits Times. (2018, May 10). Pakatan Harapan wins 14th General Election. The New Straits Times. https://www.nst.com.my/news/politics/2018/05/367907/ pakatan-harapan-wins-14thgeneral-election.

The Star, (2021, January 9). Barisan MP withdraws support for Muhyiddin, bringing Perikatan majority down to 110. The Star. https://www.thestar.com.my/news/ nation/2021/01/09/barisan-mpwithdraws-support-for-muhyiddin-bringing-perikatan-majority-down-to-110.

The Star. (2018). GE14: Results Overview. The Star. https://election.thestar.com.my/

The Star. (2020, February 26). King to meet all MPs before making decision. The Star. https://www.thestar.com.my/news/nation/2020/02/26/king-to-meet-all-mps-before-makingdecision.

The Star. (2021, January 13). Declaration of Emergency should not put democracy, rule of law in peril, says Malaysian Bar. The Star. https://www.thestar.com.my/ news/nation/2021/01/13/declarationof-emergency-should-not-put-democracy-rule-of-law-in-peril-says-malaysian-bar

Tushnet, M. (2005). Emergencies and the Idea of Constitutionalism, 50. In Tushnet, M. (2005). The Constitution in Wartime. Durham, NC: Duke University Press.

Wan Husain, W. A. F. (2017). Konsep Kedaulatan Watan Raja-Raja Melayu Dalam Perlembagaan Persekutuan Malaysia Menurut Sejarah Perundangan. (Tesis Ijazah Doktor Falsafah UndangUndang. Bangi, Universiti Kebangsaan Malaysia).

Wan Husain, W. A. F. (2018). Konsep Kedaulatan Raja-Raja Melayu Menurut Kerangka Peribumi. Selangor: Majlis Ittihad Ummah Malaysia.

Zainal, H. (2017, April 24), The Role of the Yang Di Pertuan Agung. The Star. Retrieve from https://www.thestar.com.my/news/nation/2017/04/24/the-role-of-the-yang-dipertuan-agong/ 